\title{
Effects of eight weeks resistance training on muscle hypertrophy and physiological parameters among elderly men
}

\author{
Negaresh $\mathrm{R}^{* 1}$, Ranjbar $\mathrm{R}^{2}$, Habibi $\mathrm{A}^{3}$, Gharibvand $\mathrm{MM}^{4}$
}

\begin{abstract}
Introduction and purpose: Sarcopenia is associated with reduced muscle mass, declined strength and pulmonary function in old age. The purpose of this study was to investigate effect of eight weeks resistance training on hypertrophy and physiologic parameters among elderly man.

Martials and methods: 24 elderly male subjects were randomly divided into two groups: experimental (n $=13$ ) and controls $(n=11)$. Experimental group participated in resistance training programs 3 days a week for 8 weeks while; no exercise program was offered to controls.

We measured muscle volume by $\mathrm{CT}$ scan, $\mathrm{FVC}$ and $\mathrm{FEV}_{1}$ by spirometry. Aerobic and anaerobic powers were evaluated before and after the training period.

Findings: The results showed that the sectional area $(\mathrm{p}=0 / 001)$ and muscle volume $(\mathrm{p}=0 / 004)$, were increased in the experimental group. In addition, subjects in experimental group had higher FVC $(\mathrm{p}=0 / 001)$ and $\mathrm{FEV}_{1}(\mathrm{p}=0 / 001)$, aerobic power $(\mathrm{p}=0 / 001)$, upper body $(\mathrm{p}=0 / 001)$ and lower $(\mathrm{p}=0 / 001)$ anaerobic power compared to controls.

Conclusion: Eight weeks of resistance training lead to enhanced muscle volume which may eventually improve physiological factors among elderly men. Therefore, resistance trainings can be considered as effective and safe programs to mitigate sarcopenia among elderly.
\end{abstract}

Key words: Sarcopenia, Aging, Hypertrophy, Spirometry

Received: 2016/10/3Ａccepted: 2016/11/19

\footnotetext{
Copyright () 2018 Quarterly Journal of Geriatric Nursing.This is an open-access article distributed under the terms of the Creative Commons Attribution international 4.0 International License(http://creativecommons.org/licenses/by /4.0/) which permits copy and redistribute the material, in any medium or format, provided the original work is properly cited.
}

1 - M.Sc. student of sport physiology, Department of physical education, Shahid Cahmran University, Ahvaz, Iran (Corresponding Author):E-mail: Raoof.negaresh@yahoo.com

2 - Ph.D of sport physiology, Department of physical education, Shahid Chamran University, Ahvaz, Iran

3 - Ph.D of sport physiology, Department of physical education, Shahid Chamran University, Ahvaz, Iran

4 - Ph.D of Radiology, Department of medical, Jundishapur medical science university, Ahwaz, Iran 


\title{
اثر هشت هفته تمرين مقاومتى بر برخى شاخص هاى هايبر تروفى عضلانى و فيزيولوزيك مردان سالمند
}

\section{رئوف نغارش" '، روح اله رنجبر '، عبدالحميد حبيبى '، محمد مومن غريب وندع}

\author{
تاريخ دريافت مقاله: V/N/ /

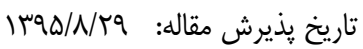

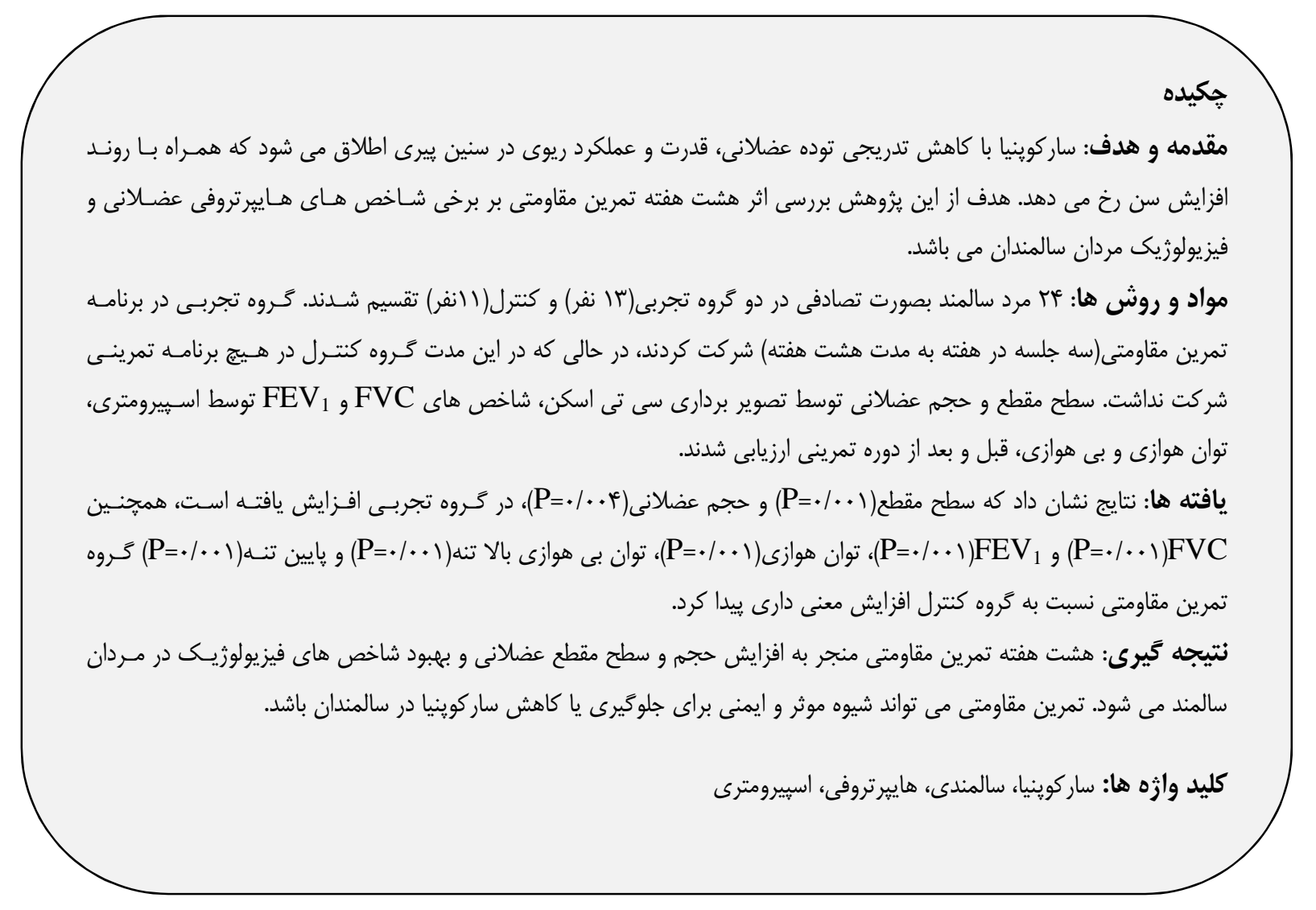

ا - دانشجوى كارشناسى ارشد فيزيولوزى ورزشى، دانشكده تربيت بدنى و علوم ورزشى، دانشخاه شهيد خمران، اهواز، ايران

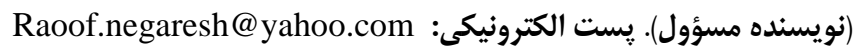

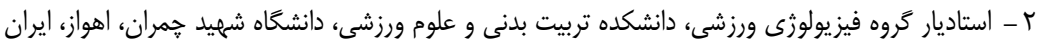

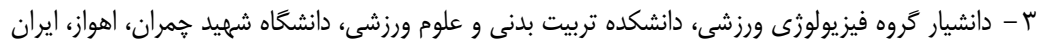

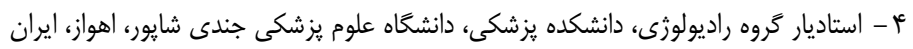


مقطع و حجم عضلانى را بدنبال تمـرين مقـاومتى گـزارش كـرده

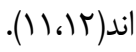

يكى ديخر از شاخص هاى افزايش سـن و سـاركوينيا، كـاهش در عملكرد ريوى مى باشد كـهـ بـا كـاهش ييشـرونده شـاخص هـاى ديناميكى مانند FEV 1 Fجلم بـازدمى بـا فشـار در يـك ثانيـه) و FVC هاى ييشين ذكر كـرده انــــــه ظرفيـت و عملكـرد ريـوى افـراد سالمند، • + درصد و حتى بيشتر نسبت به افراد جوان كـاهش مى يابد، بطورى كه كاهش قدرت عضلات تنفسى با كـاهش حجـمم و ظرفيت هاى ريوى از قبيل FEV و FVC همراه است(Fل ال). از طرفى برخى محققان گزارش كرده اند كه FEV دادن קَكَونكَى جريان هوا در مجارى تنفسى، مى توانـد بـا سـكته

مغزى، قلبى و بيمارى هاى مرتبط با كرونر مرتبط باشد (ه)). دستخاه تنفسى به همراه دستخاه قلب و عروق، نقش مهـم و ويـزّه اى را در انتقال مواد از جمله اكسيثن در درون بدن بـراى استتفاده اندام هاى مصرف كننده، ايفا مى كند. بعبـارتى دسـتخاه تـنفس و قلب و عروق رابط سيستم عضـانى اسـكلتى بــا هــواى جـو مـى باشد(f(). بدنبال يك فعاليـت بــنى، نيازهـاى متابوليـى بـدن و عضلات اسكلتى افزايش مى يابد در نتيجه اين افزايش نيازمنـدى ها، دستخاه قلب و عروق با افزايش برونده و هدايت جريـان خـون به ناحيه هاى مورد نياز سعى در فراهمى نيازمنـدى هـا مسى كنـد، همراه با اين رخداد تهويه دقيقه اى ريوى نيز افزايش مى يابـــــا دستخاه تنفس نيز در دفع مواد زايـــ و جـــب اكسـيثن نقـش ايفـا كند(ع). قطعا هر گَونه ضعف يا اختلال در فرايند مذكور، عملكـرد
ساركوينيا يا كاهش تـدريجى و اجتتـاب نايـــير تـوده عضـلانى و قدرت كه همراه با ييرى بيولوزيكى رخ مى دهـد، بـا رخــداد هـاى متنوع عضلانى از جمله، كاهش در اندازه و تعداد تارهاى عضلانى

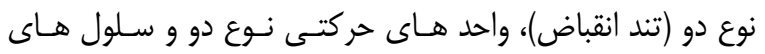
ماهواره اى تارهاى عضلانى، كاهش در تعداد هسـته هـاى تارجـهـ هاى عضلانى(()، كاهش در ميزان سنتز يروتئين هاى انقباضى و افزايش در يروتئوليز درون عضلانى (T،ب)، همـراه اسـت. بـا ايـن وجود، علت اصلى سار كوينيا بطور كامل مشخص نشده است. يكى از شيوه هاى موثر بيشنهاد شده براى جلوگيرى از سـاركوينيا يا بــه تـاخير انــاختن آن، تمـرين ورزشـى از نــوع مقـاومتى مسى باشد(أ)، نشان داده شده است كه تمرين مقاومتى منجر به افزايش سنتز روتئين انقباضى و ساختارى، بهبود روند ترجمه، افزايش در نشانگَرهاى تكثير سلول ماهواره اى و تعداد آنها، تعداد هسته هاى هر تار عضله، افزايش تمايز ميوبلاست ها و همجوشىى آنهـا مى لى

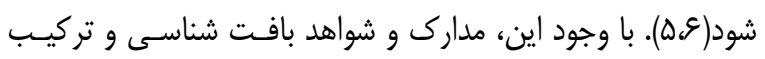
بدنى حاكى از اين است كه سازكارى هاى هاييرتروفيـى در افـراد مسن نسبت به افراد جوان محدودتر است(V). عدم فعاليت فيزيكى، يكى از عوامل مهـمه ايجـاد كنتـده و تشــديد كننده ساركوينيا شناخته شده است(ه، أ) و تحقيقات نشان داده انـــ كه مردان و زنان مسن كه از نظر فيزيكى غير فعال هستند نسـبت به افراد جوان، بيشتر در معرض كاهش تـوده عضـلانى و افزايش ناتوانى قرار دارند(^)، براى مقابله با اين كـاهش در تـوده و سـطح مقطع عضلانى ' (CSA) مطالعات زيادى اثر تمـرين مقـاومتى را بررسى كرده اند(|(1، +()، كه اغلب اين مطالعات افزايش در سـطح

\section{Cross-section area}




\section{مواد و روش ها}

يزوهش حاضر از نوع نيمه تجربى با طرح ييش آزمون-ِّ آزمون بود. جامعه آمارى آن را كليه افراد سالمند Qه تا • V سال شهرستان اهواز تشكيل مى دهند. پِس از اعلام فراخـوان و تبليـغ در سـطح شهر، از ميان افراد داوطلب براى شركت در يـرَوهش كـه شـرايط ورود به يزوهش را داشتند، عَ نفر بصورت تصادفى انتخاب شـدند و در دو گروه تجربى(سا نفر) و كنترل(النفر) قرار گرفتند. شـرايط ورود به مطالعه در اين يثوهش بجز دامنه سنى مذكور شامل: عدم مصرف سيخار، نداشتن سابقه فعاليت بـدنى مـنظم در يـك سـال كذشته، عدم استفاده از داروهايى مؤثر بر متابوليسم اسيدهاى آمينُٔ

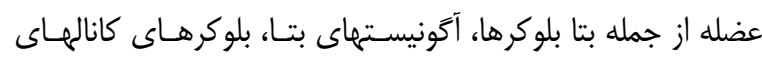
كلسيمى و كورتيكواستروئيدها يا ابتلا به بيماريهايى مزمن همجون ديابت، پاركينسون و نروياتى محيطى بـود. همجنـين افراد مـورد PAR-Q\&You بررسى قبل از شركت در يُوهش يرسشــامه را تكميل كردند، در صورت داشتن مشكل بـراى انجـام تمرينـات مانند استئويروز يا مشكلات مربوط به استخوان، مفاصل و اخـتلال حركتى شديد از مطالعه حذف شدند.

يكى هفته قبل از شروع برنامئ تمرينسى، سـه جلســُ آشـنايى بـاــا مداخلات تحقيق برَزار گرديد. در جلسه اول، از آزمودنى ها اندازه هاى آنترويومتريك قد، وزن و شاخص هاى تركيب بدنى شـامل: نمائُ توده بدن و درصد هربى بدن و همجنين اندازه گيرى يـك تكرار بيشينه گروه عضلانى هدف انجام شد. محاسبه درصد خربى

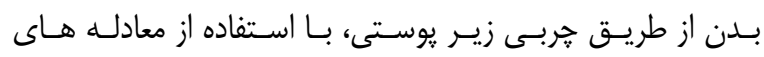

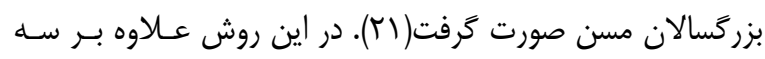
ناحيه اي كه در روش جكسون /يولاك و ايفـرد بــراى مـــدان(ران،
بهينه بدن را تحت تاثير قرار مى دهد و خستخى زودرس رادر يسى خواهد داشت. در حالى كه فعاليت بدنى منظهم مى تواند اين فراينـــ را جهت عملكرد بهينه تقويت كند(واوV|). مطالعـات متــوعى در مـورد بهتـرين روش تمرينسى بـراى بهبـود ظرفيت و عملكرد ريوى انجام شده است. يكى از ايـن شـيوه هـا تمرينات استقامتى است كه اخر خه منجر به بهبود ظرفيت تنفسى مى شود امـا تـاثير انـــكى را بــر آتروفى عضـلات بـدن و بـويزه عضلات تنفسى افراد غير فعال يا بيمار دارد. يكى ديخــر از شـيوه هاى تمرينى كه ضعف مذكور را يوشش مى دهد تمرين مقـاومتى است. براساس شواهد موجود، تمـرين مقـاومتى بــه تنهـايى يـا در تركيب با ساير شيوه هـاى تمرينـى، قـدرت عضـلانى و عملكـرد تنفسى را در بيماران مبتلا به انسداد ريوى بهبود مى بخشد(1)). اغلب يزوهش ها در زمينه عملكرد ريوى در حوزه يزشكى معطوف به بيماران مبتلا به انسداد ريوى يـا آسـه(19) و در حـوزه فعاليـت بدنى و تندرستى معطوف به ورزشكاران و افراد داراى اضـافه وزن

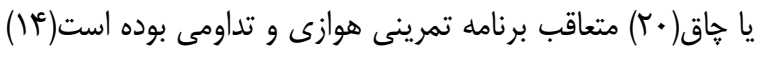
و توجه كمى به حوزه سالمندى و همجنين تمرينات مقاومتى شـده است. بنابرين با توجه به رواج زندگى كم تحرك و افزايش سـن و اثر آن ها بر حجم و سطح مقطع عضلانى، عملكرد ريوى و قدرت عضلانى، تحقيق حاضر با هدف بررسى اثـر تمـرين مقـاومتى بـر شاخص هاى هاييرتوفى عضلانى(سطح مقطع و حجم عضلانى) و برخى شاخص هاى فيزيولوزيكى(FEV)، FVC، توان هوازى و بى هوازى) مردان سالمند انجام شد. 
ركر سيون لخـاريتمى تخمـين زده مسى شـود. در ايـن شـيوه ابتـدا

آزمودنى حداكثر تكرار ممكـن را كـه مقاومـت آن توسـط محقـق

انتخاب شده بود(هدف ه تا ها تكرار)، انجام مى داد سبس بوسيله

ميزان مقاومت و تعداد تكـرار، يــ تكـرار بيشـينه محاسـبه مـى

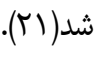

براى سنجش عملكرد ريوى قبل و سه روز پِ از پابـان يروتكـل تمرينى، از دستخاه اسيبيرومترى(مدل HI-601 ساخت كشور زاين) American براساس دستورالعمل جامعه ى قفسه سينه آمريكـا (thoracic society guidelines يس از كاليبره كـــن دسـتخاه، نحـوه انجـام آزمـون بـه شـركت كنندكان توضيح داده مى شود، پِ از ورود اطلاعات و مشخصات فردى، شركت كننده سه بار آزمون را اجرا مى كند و نتيجه بهترين نوبت، براى او ثبت مى گردد. در طول جلسات آشنايى، نمونه ها با نحوه انجام كار و روند يُوهش آشنا شدند.

براى محاسبه ميزان فعاليت بدنى شـركت كنـــدًان از يرسشـنامه فعاليت بدنى بكى(ا سوال) به روش نمره كذارى ليكرت استفاده شد. روايى محتوا و صورى اين پرسشنامه و پايايى درونى(به روش آلفا كرونباخ برابر با \&//•) محاسبه كَديده است(بَ). براى ارزيابى كيفيـت خــواب شـركت كنــــان از يرسشــامه كيفـت خـواب ييتسبورگ(PSQI)، كه ابزار مناسبى براى سنجش كيفيت خـواب سالمندان است، استفاده شد. ايـن يرسشـنامه داراى 9 سـوال در V بعد مى باشدكه مجموع امتياز هفت بعد، امتياز كـل خـواب فـرد را نشان مى دهد كه عددى بين صـفر تـا ال را شـامل مسى شـود و هرجه اين امتياز بالاتر باشد نشان دهنده كيفيت خواب نامناسب تر مى باشد. ضريب آلفاى كرونباخ آن 199/ براى نسخه فارسى ايـن يرسشنامه كزارش شده است(T) - (T).
قفسه سينه و شكم) اندازه كَيرى مى كَردد، جِهارمين جِين يوسـتى مردان بطور عمودى در محل زير بغل ميانى و در سطح بيوستـاه جناغى-جنبرى به دست مى آيد. سبِ ايـن جهـار مقـدار بدســ آمده باهم جمع مسى شـوند و در معادلـه اصـلاح شـده، قـرار داده شدند(آل). براى بدست آوردن يك تكـرار بيشـينه توسـط فرمـول براى محاسبه حداكثر اكسيثن مصـرفى از آزمـون دوخرخـهـ هـيش رونده اسـتر و ديـويس91991، اسـتفاده شــ(T). همجنـــن بـراى محاسبه توان بـى هوازى يايين تنه و بـالا تـــه از آزمـون •ب ثانيـه دوخرخه وينگَيت استفاده شد بطورى كه مقاومت اعمال شده براى

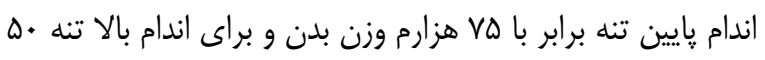

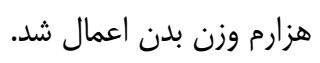
براى محاسبه سطح مقطع و حجم گروه عضلانى جهارسر ران قبل و جهار روز يس از پايان يروتكل تمرينى، از تصوير بردارى سى تى اسكن استفاده شد. تصوير بردارى بــا اسـفاده از يـك اسـكنر عباه Somatom Definition AS, اسـلايس زيمـسنس Siemens medical solution, Forchhim Germany و در حالتى كه آزمودنى هـا در حالـت خوابيـده بـــ يشت(Supine position) با پِاهـاى كشـيده هسـتند از ناحيـه ميـانى ران، دقيقـا بـين لقمـه خـارجى(Lateral condyle) Greater اسـتخوان سـاق و برجسـتخى بــزرى خــارجى trochanter استخوان ران، كَفته شد(•(). براى محاسبه حجم عضلانى، تصاوير عرضى به هم ييوسته با ضخامت يك ميلى متر و فاصله صفر ميلى متر از يايين زانو تا بالاى لكن گَرفته شد سبس Singo سطح مقطع و حجم عضله جههار سر ران توسط نرم افـزار Leonardo Singo, Siemens, Medical system, ) Germany ) تجزيه و تحليل شد. 
اى كه گروه تجربى يروتكل تمرينى را اجرا مى كرد، گروه كنتـرل هيج كَونه فعاليت ورزشى نداشتند.

داده هـاى يـزوهش بــا اسـتفاده از نـرم افـزار ( IBM SPSS SPSS (Statistics, version 21, Armonk, NY 21.0 مورد تحليل قرار كرفتند. يِ از اطمينـان از طبيعى بـودن توزيع داده ها توسط آزمون شايِيرو ويلكز و همخن بودن داده ها از آزمون تى همبسـته و تحليـل كوواريـانس بترتيـب بـراى بررسى تغييرات درون گروهى از ييش آزمون به پِ آزمون و تفاوت بـين كروهى استفاده شد. سطح معنى دارى آزمون هاى آمارى در سطح P $\mathrm{P} \unlhd 0.05$

يافته ها

در جدول شماره r يافته هـاى مربـوط بـه ويزگتى هـاى شـركت كنندكان در يزوهش در دو كروه تجربى(سا نفر) و كنتـرل(ا(انفـر)

نمايش داده شده است. نتايج اين جدول نشان دهنده اين اسـت

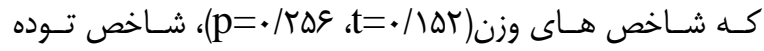

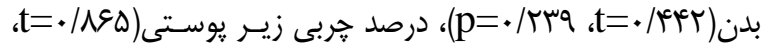

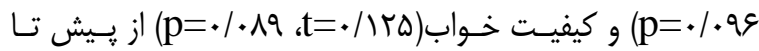
پس آزمون در هيج يك از گروه ها تغيير معنى دارى نداشته است.

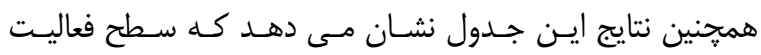

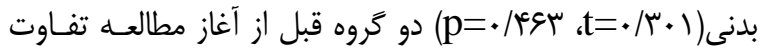

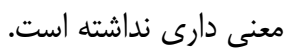

از يرسشنامه يادآمد غذايى ع ساعته در سه روز قبل(دو روز كارى و يك روز تعطيل) و حين اجراى ثروتكل تمرينسى بـراى محاسبـه كالرى برنامه غذايى استفاده شد. در اين روش از جــاول مرجـع و استاندارد براى تبديل واحد ها و ييمانه هاى خانكى به گرم استفاده شد، سيس اطلاعات براى محاسبه انرزى تام، درصد انرزى حاصل

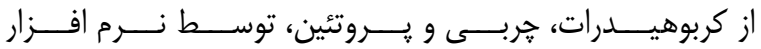
Nutritionist4 برنامه تمرينىى: مداخله تمرينى مشتمل بـر هشـت هفتـه و هــر هفته سه جلسه تمرين مقـاومتى در گَروه تجربسى بـود. يروتكـل

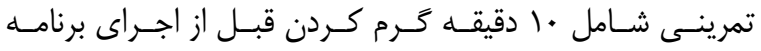
اصلى(حركات كششى، راه رفتن، جاگينگ و دويدن نرم) و ه دقيقه سرد كردن پِ از اجراى برنامه در هر جلسه بود. يروتكل تمرينى شامل تمرين با وزنه براى گروه هاى عضلانى جلو بازو، پشت بازو، جلو ران، پشت ران، قفسه سينه، شـمم و سرشـانه بود. بدين منظور از حركات جلو ران نشسته با دسـتخاه، يشـت ران خوابيده با دستخاه و اسكوات براى اندام يـايين تنـه، يـرس سـينه خوابيده، قفسه سينه با دستكاه ، شكم، زير شكم و زير بغـل سـيم كش براى عضلات مركزى تنه و جلو بازو با هالتر، يشت بازو سيم كش و سرشانه با دستخاه براى اندام بالا تنه در نظـر گرفتـه شــ. مقدرا وزنه تمرينى براساس ركورد يك تكرار بيشينه و طبق جدول شمارها اعمال شد. تعداد ست ها براى هر حركت، أ ست در نظر كرفته شد. تعداد تكرارهاى هر ست برابر بــا ــ ا و اسـتراحت بـين ست ها نيز يك دقيقه، همجنين استراحت بين دو حركت مختلـف، سه دقيقه در نظر گرفته شده بود. ضرب آهنگ تكرارها نيز بوسيله مترونوم تنظيم مى شد بطورى كه هر حركت به مدت r ثانيه (يك ثانيه درونكرا و يك ثانيه برونكرا) طول مى كشيد. در هشت هفتـه 
جدول ا. نمايش افزايش شدت برنامه تمرين مقاومتى گروه تجربى

\begin{tabular}{|c|c|c|c|c|}
\hline $\begin{array}{c}\text { شدت(درصد از } \\
\text { (1RM }\end{array}$ & تعداد تكرار * تعداد ست & استراحت بين & استراحت بين & هفته \\
\hline م مرصد & $f_{* 1}$ & يك دقيقه & سه دقيقه & اول \\
\hline ه ه درصد & $f * 1$ & يك دقيقه & سه دقيقه & دوم \\
\hline . & $r * 1$. & يك دقيقه & سه دقيقه & سوم \\
\hline هو درصد & $f_{* 1}$. & يك دقيقه & سه دقيقه & جهمارم \\
\hline V Vرصد V. & $f * 1$. & يك دقيقه & سه دقيقه & هنجم \\
\hline Va درصد VQ & $f * 1$. & يك دقيقه & سه دقيقه & ششم \\
\hline م مرصد. & $r_{* 1}$. & يك دقيقه & سه دقيقه & هفتم \\
\hline هم درصد & $f * 1$. & يك دقيقه & سه دقيقه & هشته \\
\hline
\end{tabular}

جدول r. برخى ويزتى هاى شركت كنندَان در مطالعه به تفكيك تروه ها

\begin{tabular}{|c|c|c|c|}
\hline يس آزمون & ي ي يش آزمون & كروه & متغيير \\
\hline- & $\Delta q / \varepsilon I \pm r / V r$ & تجربى & سن (سال) \\
\hline- & 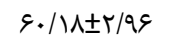 & كنترل & \\
\hline- & IVT/VYEA/gT & تجربى & قد (سانتى متر) \\
\hline- & $\mid V T / \mathcal{G} \pm \Delta \Delta / I r$ & كنترل & \\
\hline$V 9 / \Delta \& \pm \Delta .1 T$ & $V Q / \Delta I \pm \& / / f$ & تجربى & وزن (كيلو \\
\hline$\left.V \Delta / F \pm V . f^{c}\right)$ & $V Q / \varepsilon+ \pm \Phi / \Lambda$. & 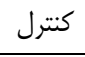 & \\
\hline 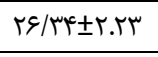 & $r \varepsilon / \varepsilon r \pm r / . q$ & تجربى & شاخص توده ى بدن \\
\hline$r \Delta / \Delta \wedge \pm r / \& V$ & $r \Delta / F I \pm r / F r$ & كنترل & (كيلوكَرم/ متر مربع) \\
\hline$M E / A T \pm T / I V$ & $r \leftarrow / ৭ 9 \pm T / \& q$ & تجربى & درصد جربى (درصد) \\
\hline$\Gamma Y / \Lambda V \pm \Psi / \Gamma \Delta$ & $r(\Lambda) \pm m / F)$ & كنترل & \\
\hline- & $r \varepsilon / q 1 \pm 1 \varepsilon / 1 \varepsilon$ & تجربى & ميزان فعاليت بدنى \\
\hline- & $r e / 4 r \pm T M / M$ & كنترل & \\
\hline$F / r r \pm r / V r$ & $\Delta / I Y \pm T / M$ & تجربى & وضعيت خواب \\
\hline$\Gamma / q r \pm I / \Lambda \Delta$ & $r / q \Delta \pm r / q \Lambda$ & كنترل & \\
\hline
\end{tabular}




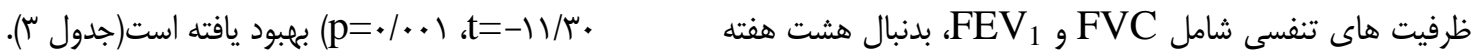

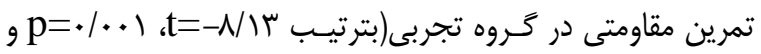

جدول r. مقايسه تاثير تمرين مقاومتى بر برخى شاخص هاى ريوى به تفكيك تروه ها

\begin{tabular}{|c|c|c|c|c|c|c|c|}
\hline \multicolumn{2}{|c|}{ بين كَروهى } & \multicolumn{2}{|c|}{ درون تَروهى } & \multirow[t]{2}{*}{ پِ آزمون } & \multirow[t]{2}{*}{ ييش أزمون } & \multirow[t]{2}{*}{ تَروه } & \multirow[t]{2}{*}{ متغيير } \\
\hline $\mathrm{P}$ & $\mathrm{F}$ & $P$ & $\mathrm{~T}$ & & & & \\
\hline \multirow[t]{2}{*}{$\cdot / \cdot \cdot *$} & \multirow[t]{2}{*}{$9 N / \% 1$} &.$/ .1 \%$ & r & $r / .9 \pm \cdot / r$. & $r / \Delta T \pm . / M$ & تجربى & \multirow[t]{2}{*}{ (ليتر)FVC } \\
\hline & &.$/ M F$ & $1 / 9 \mathrm{~V}$ & $r / Q 1 \pm . / T r$ & $r / \Delta F \pm \cdot / r T$ & كنترل & \\
\hline \multirow[t]{2}{*}{ • $/ . .1 \%$} & \multirow[t]{2}{*}{$1 . . / 11$} & $\cdot / \cdot 1 *$ & $-|1 / \mu|$ & $r / M \perp \pm / / q$ & $r / r \cdot \pm \cdot / / \Lambda$ & تجربى & \multirow[t]{2}{*}{ (ليتر)FEV } \\
\hline & &.$/ 01 \Lambda$ &.$- / 8 \mathrm{~V}$ & $r / r r \pm . / r)$ & $r / r \Psi \pm . / r)$ & كنترل & \\
\hline
\end{tabular}

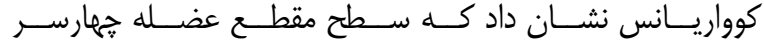

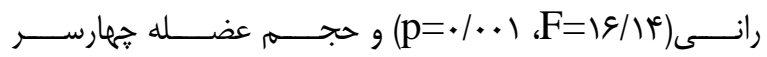

رانى(

تمرين مقاومتى افزايش يافته است.
نتايج حاصل از جدول ع نيز نشان مى دهد كه توان هوازى(\$|\&/F-

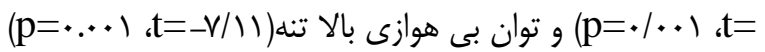

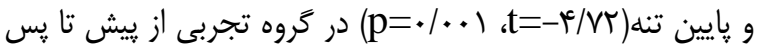

آزمون فزايش معنى دار يافته است. علاوه بر اين نتايج تحليل

جدول س. مقايسه تاثير تمرين مقاومتى بر توان هوازى، بـ هوازى و هايبر تروفى عضلانى به تفكيك تروه ها

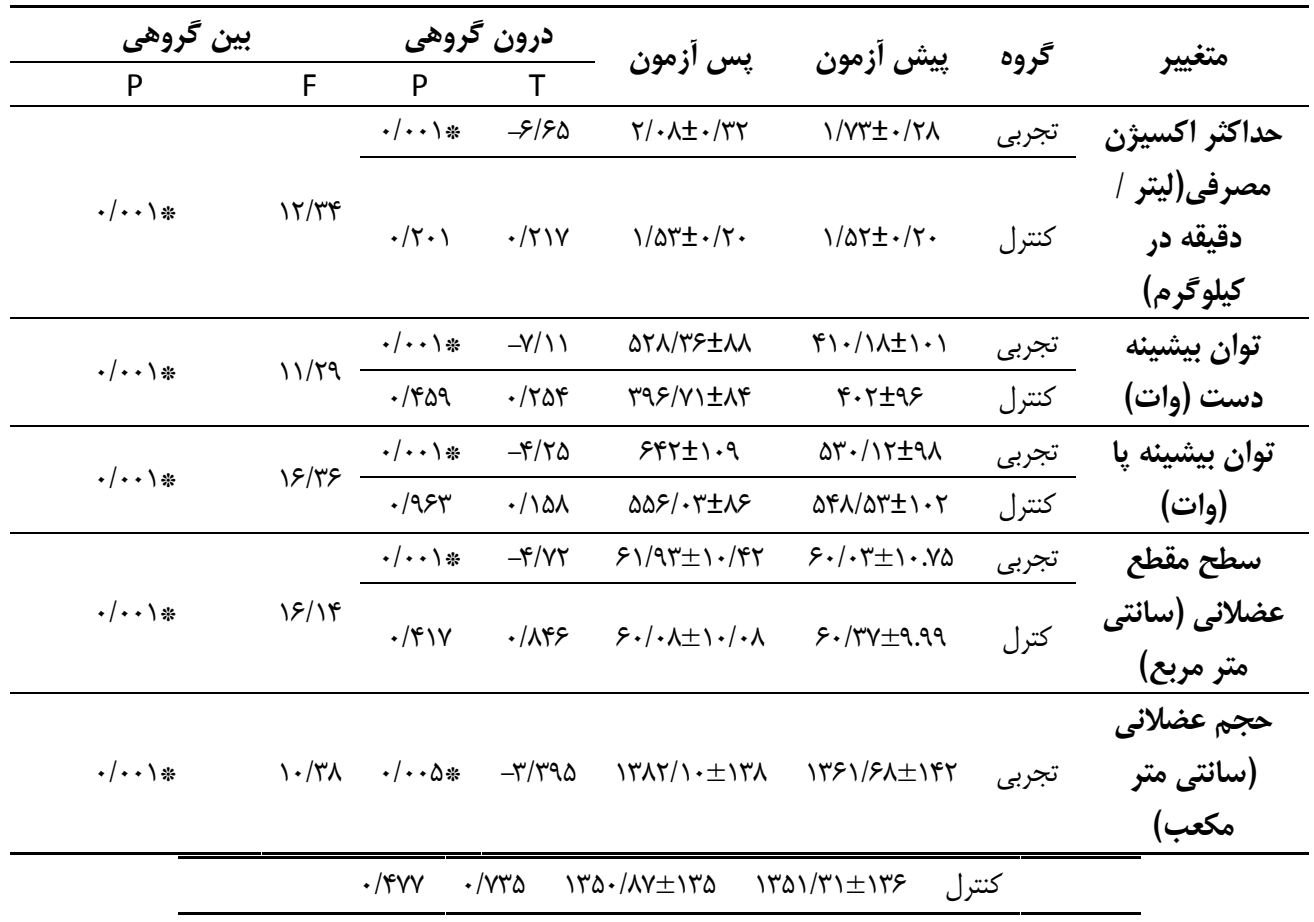


كل كالرى دريافتى در كروه تجربى(·V\&

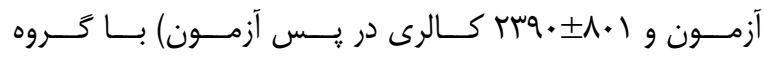

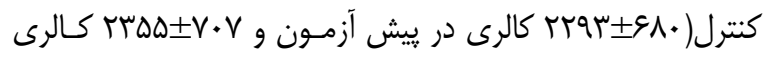

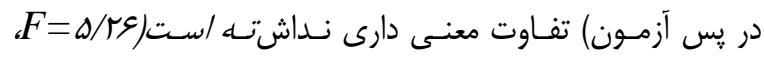

$$
\cdot(p=\cdot / 1 r a
$$

با بررسى وضعيت دريافت كالرى كلى برنامه غذايى و سه زير گروه كربوهيدرات، جربى و يروتئين از نمودار ا مشخص مى شود كه

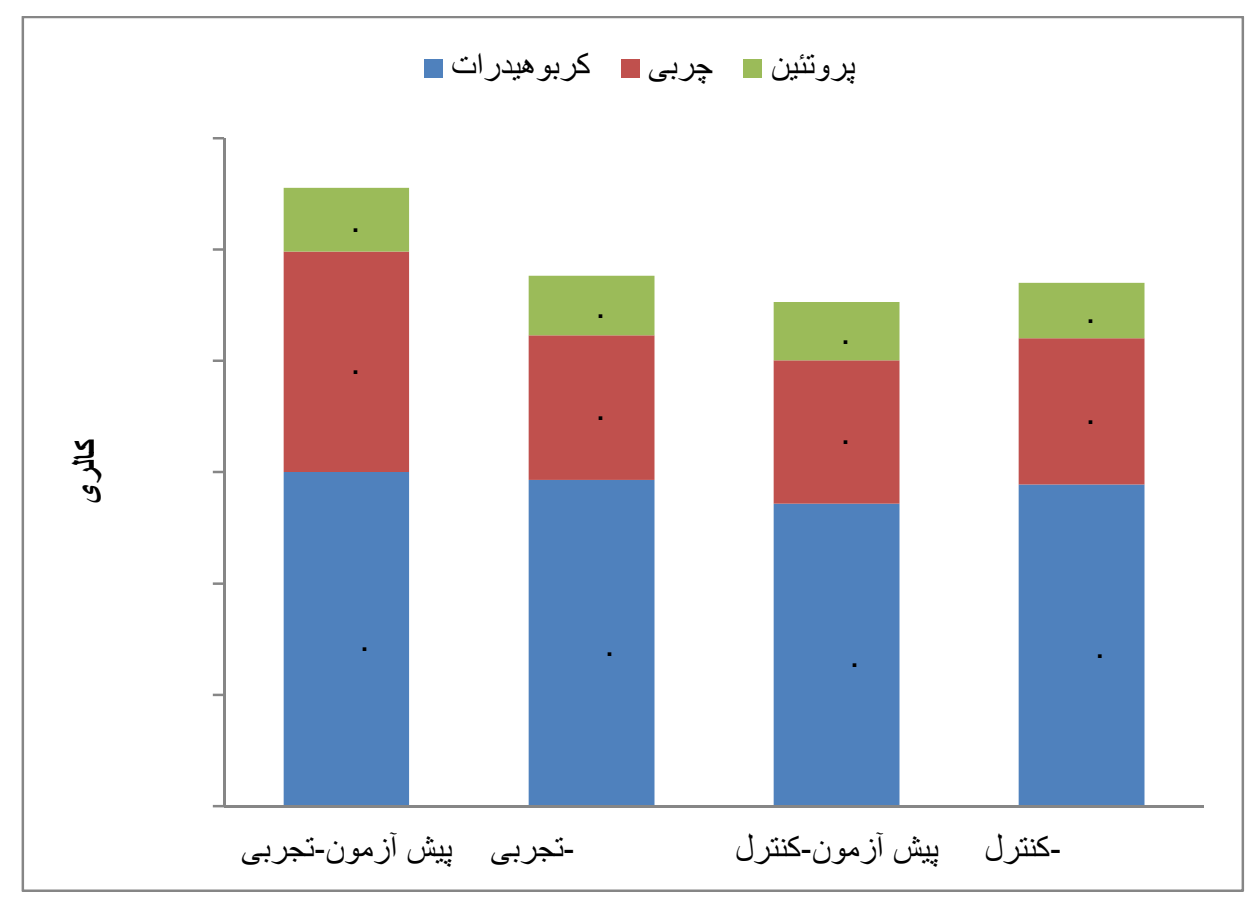

نمودار (. مقايسه كالرى برنامه غذايى مصرفى از تَروه هاى غذايى مختلف به تفكيك تَروه ها

بحث و نتيجه تيرى

و كاهش عملكرد ريوى در بزرَسالان و سـالمندان را تاييـد كرده اند(Tه). على رغهم اينكـهـ روابـط متقابـل بـين قــــت عضـلانى و عملكرد ريوى در سالمندان كمتر مورد توجه قرار گرفته است،
سـالمندى بـا كـاهش تـوده ع عضـلانى و قــدرت بـويزه قــدرت عضلانى، منجر به كاهش ظرفيت عملكردى فرد مى شود. برخى از مطالعات تغييرات منفى را در ساختار و عملكرد عضلانى بدنبال 


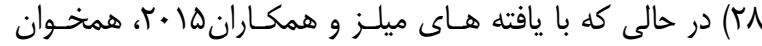
نيست. در يزوهش ميلز و همكاران ها •r، مشاهده شد كـه هشـت هفته تمرين در سالمندان منجر به افزايش FVC نشده است كـهـ آن را به عدم تغيير در فاكتورهاى التهابى ريوى مانند اينترلوكين و عامل نكروز بافت آلفا نسبت داده انــــ از دلايـل منــايرت نتـايج بدست آمده در يزوهش حاضر با يزوهش ميلز و همكـارانها +r، مى توان به تفاوت در نوع، شدت و مدت تمرين بكار رفتـه اشـاره

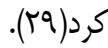

يُوهش حاضر همجنين نشان داد كه يـك دوره هشت هفتـه اى تمرين مقاومتى با افزايش در FVE همراه بوده است. يافته هاى اين يزوهش با يافته هاى مهرى زاده و همكـاران سوسا و نـاظهم و

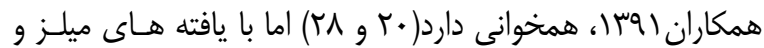

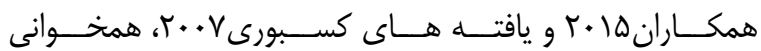

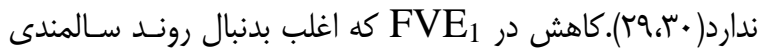
رخ مى دهد مى تواند بازتابى از كـاهش مجمـوع ظرفيـت ريـوى، انسداد راه هاى هوايى، از دست رفتن نيروى برگشت يـذيرى و يـا رشد نامتعارف عضلات تنفسى باشد. لذا انتظار مسى رود بـا بهبــود قدرت و همـاهنكَى سيسـتم عصـبى عضـالانى، FVE يابد(ع)). با توجه به اينكه بخشى از برنامه تمرينسى بكـار رفتـه در يثوهش حاضر بطور اختصاصى عضلات مركزى بدن را هدف قرار داده بود مى توان يكى از دلايل بهبود FVE را به بهبود قـدرت عضلات تنفسى نسبت داد.

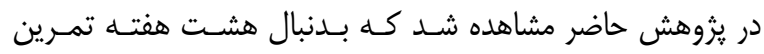
مقاومتى، توان هوازى و بـى هـوازى افـزايش معنى دارى يافت. افزايشى كه در توان هوازى و بى هوازى كروه تمرين مقاومتى نيز مشـاهده شـد مسى توانــد متــاثر از بهبــود در همــاهنخى عصـب و
عملكرد ريوى در دوران ييرى حتى در غياب عوامل خارجى تشديد كننده اى مانند آلاينده هاى خارجى(سيخار كشـيدن) كـاهش مسى يابد(ع)). كاهش در عملكـرد ريـوى مسى توانـــــــــ ظرفيـت عملكردى و ورزشى و به دنبال آن ار دست دادن قدرت عضـلانى، آتروفى عضلانى و افزايش خطر ابتلا به بيمارى انسداد ريوى را در يى داشته باشد(مه). بنظر مى رسد كه كاهش قـدرت عضـلانى(در سالمندان) آغازمر زنجيره اي از تغييرات مرتبط با سن باشد كـهـ بــا كاهش عملكرد ريوى، كاهش قدرت و استقامت عضلات تنفسى و كاهش ظرفيت عملكرد ورزشى همراه است. مطالعات متعدد نشـان داده اند كه فعاليت فيزيكى ممكن است از كاهش وابسته بـه سـن در عملكرد عضلانى و ريـوى بكاهـد(أ و وץ). انجمـن ورزشى آمريكا، انجام تمرينات مقاومتى را بــراى بهبـود كيفيـت زنـدَى و عملكرد فيزيكى سالمندان و كنترل روند سـاركوينيا توصـيه كـرده است و اين شيوه تمرينى را راهكارى ضرورى و موثر در سالمندان

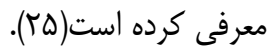
نتايج بركرفته از اين يزوهش نشان داد كـه هشـت هفتـه تمـرين مقاومتى در سالمندان با افزايش معنى دار FVC و FVE همراه است. FVC يا ظرفيـت حيـاتى اجبـارى يكى از شـاخص هـاى يويايى ريوى است كه به سن، سطح فعاليت بدنى، شيوه زنـدگى و تركيب بدنى وابسته اسـت. ارزش ايـن شـاخص اغلـب بــا قــــت عضلات تنفسى و عملكرد ريـه هـا، مقاومـت راه هـاى هـوايى و

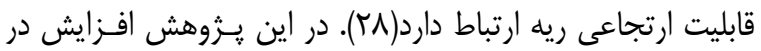
را مى توان با بهبود قدرت و استقامت عضـلات بـه ويـرَه عضلات ثبات دهنده مركزى بدن و همـاهنكَى عصـبى عضـلانى نسبت داد. نتايج حاصل از يزوهش حاضر با يافته هاى مهدى زاده و همكاران سوسا و ناظم و همكـاران (qسا، همخـوان اسـت(·r و 
كالرى كلـى برنامـه غـذايى و ميـزان كـالرى دريـافتى از درشـت

مغذهاى مختلف مانند يروتئين بـين دو گـروه تفـاوت معنسى دارى

نداشته است. تمرين مقاومتى مى توانــــ از طريـق مكـانيزم هـاى مختلفى هاييرتروفى عضلانى را افزايش دهد. مطالعات كَنـاگونى در گروه هاى سنى مختلف نشان داده اند كه تمرين مقــاومتى بــهـ

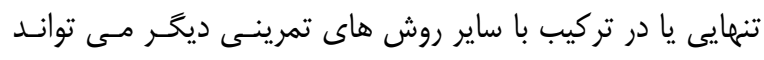
تعادل نيتروزنى(يروتئينى) عضله اسـكلتى را متـاثر سـازد و تعـادل نيتروزنى را در جهت مثبت و آنابوليسم سـوق دهــ(rV و اr) كـهـ بدنبال آن در بلند مدت، افزايش در سطح مقطع و حجم عضـلانى مشاهده مى شود. در مجموع نتايج اين يزوهش نشان مى دهد كه تمرين مقاومتى مى تواند روند ساركوينيا و كاهش حجم عضـلانى را تحت تاثير قرار دهد، همجنين بهبود شـاخص هـاى ريـوى نيـز مشاهده شد.

\section{تشكر و قدردانى}

اين مقاله بركَفته از يايان نامه كارشناسى ارشد مصوب در دانشگاه شهيد جمران اهواز اسـت. بـــين وسـيله از رياسـت محتـرم حَروه راديولـوزى دانشـعاه جنـــى شـايور اهـواز، يرســل راديولــوزى بيمارستان كَلسـتان اهـواز، شـركت كنــدكان در يـرَوهش و تمـام افرادى كه در اجراى هرجه بهتــر ايـن يـروهش يـارى كـرده انـد،

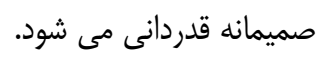

عضلانى(اثر سريع تمرينات مقاومتى) و افزايش در سطح مقطع و حجم عضلانى(اثر كند تر تمرين مقاومتى) باشد(TV و آس). سـطح مقطع و حجم عضله با توليد نيرو رابطه مستقيمى را دارد به كَنسه اى كه سطح مقطع و حجم بالاتر يك عضله با افـزايش بيشـتر در تنش و نيرو عضله همراه است، در نتيجه مى تواند توان بى هوازى را متاثر سازد. همجنين هماهنخَى عصبى عضلانى حاصـل بــنبال تمرين مقاومتى كه در مطالعات متعددى ذكر شده است مـى توانـــ استفاده بجينه تر و اقتصادى تر از نيرو مكـانيكى عضـله رادر يسى

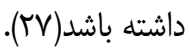
نتايج يزوهش حاضر همجنين نشان داد كه افزايش در توان هوازى

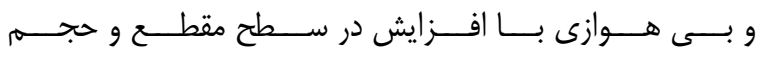
عضلانى(هاييرتروفى) همراه است. عضله اسكلتى بالغ، يك بافت ناهمگَون، جند هسته اى و يـس ميتـوزى اسـت كـه داراى انـواع مختلفى از تارها با عملكرد هاى گَوناگون مى باشد كه قـادر اسـت ساختار، عملكرد، متابوليسم و خواص ملكولى-بيولوزيكى خود را در

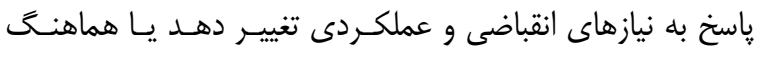
كند(ه و TV). افزايش در سطح مقطع و حجم عضـله بجـز عوامـل زنتيكى مى تواند متاثر از عوامل محيطى متعددى باشد كه به طور ويزه تمرين، خواب و رزيم غذايى مى توانند نقـش مهمى را ايفـا كنند(r). در اين يزوهش مشاهده شد كه كيفيـت خـواب دو گَروه مورد مطالعه تفاوت معنى دارى نداشت. همجنـين ميـزان دريافت 


\section{- References}

1. Alway SE, Siu PM. Nuclear apoptosis contributes to sarcopenia. Exerc Sport Sci Rev. 2008;36(2):51-7.

2. Trappe T, Williams R, Carrithers J, Raue U, Esmarck B, Kjaer M, et al. Influence of age and resistance exercise on human skeletal muscle proteolysis: a microdialysis approach. J Physiol. 2004;554:803-13.

3. Macintosh BR, Gardiner PF, McComas AJ. Skeletal muscle from and function. 2 ed. Champaighn: Human Kinetics; 2006.

4.Houston DK, Nicklas BJ, Ding J, Harris TB, Tylavsky FA, Newman AB, et al. Dietary protein intake is associated with lean mass change in older, community-dwelling adults: the Health, Aging, and Body Composition (Health ABC) Study. Am J Clin Nutri. 2008;87(1):150-5.

5. Verdijk LB, Gleeson BG, Jonkers RA, Meijer K, Savelberg HH, Dendale P, et al. Skeletal muscle hypertrophy following resistance training is accompanied by a fiber type-specific increase in satellite cell content in elderly men. J Gerontol A Biol Sci Med Sci. 2009;64(3):3329.

6. Kumar V, Selby A, Rankin D, Patel R, Atherton P, Hildebrandt W, et al. Age-related differences in the dose-response relationship of muscle protein synthesis to resistance exercise in young and old men. J physiol. 2009;587(1):211-7.

7. Petrella JK, Kim JS, Mayhew DL, Cross JM, Bamman MM. Potent myofiber hypertrophy during resistance training in humans is associated with satellite cell-mediated myonuclear addition: a cluster analysis. J Appl Physiol. 2008;104(6):1736-42.

8. Delshad M, Ebrahim K, Gholami M, Ghanbarian A. [The effect of resistance training on the prevention of sarcopenia in women over 50 years]. J Bioscience. 2011;8(1):123-39. (Persian)

9. O'Hagan FT, Sale DG, MacDougall JD, Garner SH. Response to resistance training in young women and men. Int J Sports Med. 1995;16(5):314-21.

10. Abe T, Kearns CF, Fukunaga T. Sex differences in whole body skeletal muscle mass measured by magnetic resonance imaging and its distribution in young Japanese adults. Br $\mathbf{J}$ Sports Med. 2003;37(5):436-40.

11. Aguiar AF, Buzzachera CF, Pereira RM, Sanches VC, Januario RB, da Silva RA, et al. A single set of exhaustive exercise before resistance training improves muscular performance in young men. Eur J Appl Physiol. 2015;115(7):1589-99. 
12. Falah A, Khayambashi K, Rahnama N, Ghoddousi N. [Effects of hip abductor and external rotators strengthening and quadriceps strengthening in females with patellofemoral pain syndrome: A comparative study]. J Res Rehabil Sci. 2012;8(2):354-62. (Persian)

13. Gramiccioni C, Carpagnano GE, Spanevello A, Turchiarelli V, Cagnazzo MG, Foschino Barbaro MP. Airways oxidative stress, lung function and cognitive impairment in aging. Monaldi archives for chest disease $=$ Archivio Monaldi per le malattie del torace / Fondazione clinica del lavoro, IRCCS [and] Istituto di clinica tisiologica e malattie apparato respiratorio, Universita di Napoli, Secondo ateneo. 2010;73(1):5-11.

14. Hosseini SRA, Oshtovani ZH, Soltani H, Kakhk SAH. [Changes in Pulmonary Function and Peak Oxygen Consumption in Response to Interval Aerobic Training in Sedentary Girls]. J Sabzevar Uni Med Sci. 2012;19(1):42-51. (Persian)

15. Abdollahi M, Roshan VAD, Hosini SM. [The effect of different age groups and protocol (ergometer feet in the hand cycling) on men lung function]. J Bioscience. 2015;7(1):141-55. (Persian)

16. Thaman RG, Arora A, Bachhel R. Effect of physical training on pulmonary function tests in border security force trainees of india. J Life Sci. 2010;2(1):11-5.

17. Troosters T, Gosselink R, Janssens W, Decramer M. Exercise training and pulmonary rehabilitation: new insights and remaining challenges. Eur Respir Rev. 2010;19(115):24-9.

18. Tofighi A, ameri MS, azar JT. [The effects of twelve weeks of endurance, strength and Concurrent training on lung volume and capacity of sedentary students]. J Olampic. 2012;20(52):99-111. (Persian)

19. Moghaddasi B, Moghaddasi Z, Nasab PT. [The effect of physical exercise on lung function and clinical manifestations of asthmatic patients]. Arak Med Uni J. 2010;13(2):134-40. (Persian) 20. Nazem F, Izadi M, Keshavarz B, Jalili M. [Impact of aerobic exercise and detraining on pulmonary function indexes in obese middle-aged patients with chronic asthma]. Arak Med Uni J. 2013;15(68):86-93. (Persian)

21. Adames Gm. Exercise Physiology Laboratory Manual. 3 ed. Tehran: Hatmi publisher; 2014.

22. Storer TW, Davis JA, Caiozzo VJ. Accurate prediction of VO2max in cycle ergometry. Med Sci Sports Exerc. 1990;22(5):704-12. 
23. Tofighi A, Babaei S, Kashkooli Fi, Babaei R. [The relationship between the amount of physical activity and general health in urmia medical university students]. J Urmia Nurs Midwifery Faculty. 2014;12(3):166-72. (Persian)

24. Najafi Z, Tagharobi Z, Shahriari M. [Effect of aromatherapy with lavender on quality of sleep in patients undergoing hemodialysis]. J Feize. 2014;18(2):145-50. [Persian]

25. Sillanpaa E, Stenroth L, Bijlsma AY, Rantanen T, McPhee JS, Maden-Wilkinson TM, et al. Associations between muscle strength, spirometric pulmonary function and mobility in healthy older adults. Age. 2014;36(4):9667.

26. Degens H, Maden-Wilkinson TM, Ireland A, Korhonen MT, Suominen H, Heinonen A, et al. Relationship between ventilatory function and age in master athletes and a sedentary reference population. Age. 2013;35(3):1007-15.

27. Farrell PF, Joyner MJ, Cayozzo VJ. ACSM,s Advenced exercise physiology. 2 ed. Philadelphia,: Am College Sports Med; 2012.

28. Mehdizadeh R, Razavian-Zadeh N, Haseli S. [The effect of core resistance trainings on functional indices of lung in obese women with type II diabetes]. Sci-Res J Shahed Uni. 2014;110(21):1-11. (Persian)

29. Mills DE, Johnson MA, Barnett YA, Smith WH, Sharpe GR. The effects of inspiratory muscle training in older adults. Med. Sci Sports Exerc. 2015;47(4):691-7.

30. Casaburi R, Bhasin S, Cosentino L, Porszasz J, Somfay A, Lewis MI, et al. Effects of testosterone and resistance training in men with chronic obstructive pulmonary disease. Am $\mathbf{J}$ Respir Crit Care Med. 2004;170(8):870-8.

31. Phillips SM. Physiologic and molecular bases of muscle hypertrophy and atrophy: impact of resistance exercise on human skeletal muscle (protein and exercise dose effects). Appl Physiol Nutr Metab. 2009;34(3):403-10. 